de Vries found at Hilversum and observed his classical series of mutations in.

Three of these strains, from widely different sources, may be referred to.

In September, I904, Mr. E. P. Bicknell, of Nantucket City, sent two sheets of dried material to the Botanic Garden at New York. The seeds of these specimens were sown in sterilised soil in November of the same year, and amongst the seedlings raised six corresponded exactly to the mutant CE. albida raised by de Vries.

Amongst the seedlings raised from a packet of seed supplied by MM. Vilmorin et Cie., of Paris, there were one $C E$. lata, one nanella, and one albida.

Lastly, some plants and seeds of a form provisionally called CEnothera "biennis" (Linnæus) were sent over from this country by Mr. H. Stuart Thompson, who had collected the actual seed he sent near Bidston Junction, not far from Liverpool. The plants raised from these seeds proved to be identical with the CEnothera Lamarckiana of de Vries, and the strain turned out, like that studied by de

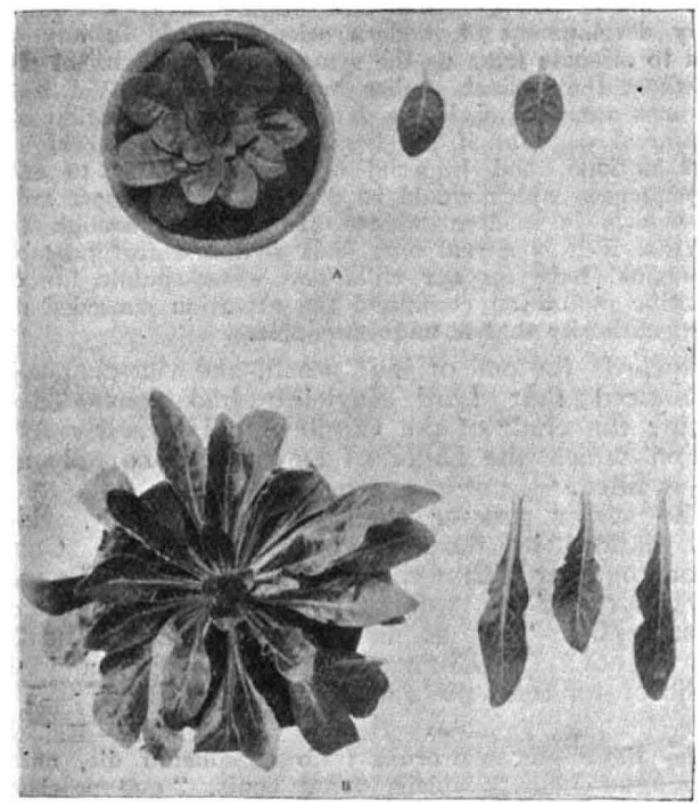

a. Rosette of Enotnera lata, four months'old, separate leaves of the same age. B. Rosette of Enothera albida, four months old, and separate leaves of the same age.

Vries, to be in a mutable state; for it gave rise to no less than four of the mutants which appeared at Amsterdam-namely, $O E$. lata, oblonga, albida, and subrinervis.

A. D. D.

\section{THE INDIAN INSTITUTE OF SCIENCE.}

$\mathrm{N}$ a recent article on the Jubilee of the Calcutta University it was shown that considerable efforts have been made in Bengal during the last few years to raise the level and tone of university education, and to render it more thorough and practical. Similar efforts are also being made in other parts of India by the Universities of Madras, Bombay, the Punjab and Allahabad, so that it may be hoped that a fairly high standard of university education will be main. tained in future in India. Other indications also show that India is becoming alive to the necessity of modelling its educational system on the most modern European lines from the lower forms up to the very highest. The Indian Institute of Science, which is now being started at Bangalore, in Southern India, is an instance in point, and shows how the most advanced of the thinkers in India have grasped the necessity for the prosecution of the very highest forms of post-graduate work. Bangalore, which has been finally chosen for the site of the new institute, has (for India) a most excellent climate; it is situated about 3000 feet above sea-level, and the temperature there is never excessive, so that the conditions for work will be most favourable.

The institute owes its inception to the munificent generosity of the late Mr. J. N. Tata, a Parsee millionaire, who gave (during his lifetime) property which brings in an annual income of about Rs. $1,25,000(8333 l$.$) for the creation of an institute$ to be devoted to original research. Before the arrangements as to the endowment had been completed $\mathrm{Mr}$. J. N. Tata died, but his two sons, Mr. D. J. Tata and Mr. R. J. Tata, have generously continued the arrangements made by their father.

Considerable discussion ensued as to the best method of utilising this endowment, and a committee was first formed in India to discuss it. Later Sir William Ramsay was asked by Mr. Tata to visit India and advise on the subject; and still later a committee consisting of Prof. Masson and Col. Clibborn made a report as to the best site for the institute and the best scheme of work. The final scheme, however, has been largely worked out by Dr. Morris W. Travers, F.R.S., who was appointed director of the institute about two years ago.

The actual starting of the institute has been much facilitated by two munificent gifts from H.H. the Maharajah of Mysore, who has made a grant of half a square mile of land at Bangalore (in Mysore) for the purpose of the institute, and has also given an annual endowment of half a lakh of rupees (3333l.). This has also been supplemented by an annual grant of Rs. 87,500 (about $5833 l$.) from the Government of India, so that the institute. will have an annual income of at least Rs. $2,62,500$ (nearly I8,oool.) for its work.

In addition, too, the Maharajah of Mysore has given five lakhs of rupees, and the Government of India two and a half lakhs, for the erection of buildings, and these sums, together with the accumulations of interest, will give about ten lakhs of rupees $(66,666 l$.$) , and the buildings are to be proceeded with$ at once.

The constitution of the governing body has been decided on, and the greater part of the detailed initiam tive has been left to a local committee, consisting largely of the director of the institute and professors of the staff. Practically only post-graduate work and research will be carried on in the institute, and from its nature and position it will be able to attract the cream of the graduates and intellect of India. Provision is to be made for about sixty students to be at work. The subjects which will be taken up are those which are likely to have an important influence in the development of the various arts and industries of India. To begin the work of the institute, for the present five subjects have been decided on : pure and applied chemistry, organic chemistry, bacteriology and the study of fermentation processes, and electrical technology. Probably a sixth (metallurgy) will be added shortly.

India is thus bringing itself into line with the most advanced European countries in the matter of high education, and it may be hoped that every possible success will attend the new institute in its work.

NO. 20IO, VOL. 78] 